\title{
Competitiveness Analysis and Factors Affecting Trade of Main Commodities between Indonesia and Turkey
}

\author{
Fauziyah Adzimatinur \\ Faculty of Economics, University of Kuningan \\ f.adzimatinur@uniku.ac.id
}

\begin{abstract}
This study aims to analyze the competitiveness, trade integration, trade complementarity, and factors affecting the export and import of main commodities between Indonesia and Turkey. Data used in this study is time series data in 1996-2018 and the methods used are Revealed Comparative Advantage (RCA), Intra-Industry Trade (IIT), Trade Complementarity Index $(\mathrm{TCl})$, and Ordinary Least Square (OLS). Results of RCA showed Indonesia's main export commodities to Turkey are woven fabrics, stearic acid, palm oil and natural rubber. While IIT showed that there is only one way trade from Indonesia. Import commodities from Turkey are carpets, borax, wheat flour, and tobacco. $\mathrm{TCl}$ showed low complementarity between Indonesia's export and Turkey's import. GDP per capita has positive impact on exports and imports. The exchange rate has positive impact on exports and negative on imports. Price and tariff rate have negative impact on both exports and imports. Dummy Non-tariff barrier has negative impact on exports while in import side, it only affects the wheat flour negatively. The Government of Indonesia should pursue a strategy in trade cooperation as efforts to reduce trade barriers such as tariffs and non-tariffs for some commodities that have competitiveness in the Turkish market.
\end{abstract}

Keywords: Competitiveness, Trade, Export Demand JEL Classification: F10

\section{INTRODUCTION}

Indonesia is currently under the process of trade cooperation negotiation with Turkey. Stage of cooperation is currently at the stage of Joint Study Group (JSG). The JSG phase examines the potential trade between the two countries. The third meeting of JSG was held in Ankara, Turkey, February 24-26th 2011. Indonesia is studying the possibility to hold a Comprehensive Economic Partnership Agreement with the European Union. Countries in the European Union is the main trading partner of Turkey, so there are opportunities for Indonesia to develop its trade by utilizing the Turkish position. Turkey can be used as a stepping stone for Indonesian export products in order to penetrate the market in European Union (EU) as well as the market in Central Asia countries such as Uzbekistan, Azerbaijan, Kazakhstan and Turkmenistan.

International trade allows countries to specialize in the production of goods that can be made efficiently, so as to increase 
efficiency and production scale. A country needs to create trading strategies related to commodity that has competitiveness in international trade. Based on data from Indonesia Ministry of Industry (2014), the top industrial product exported by Indonesia to Turkey include textiles, processing coconut/palm, rubber processing, basic chemicals, and pulp and paper. While the industrial products imported from Turkey include textiles; steel, machinery, and automotive; basic chemistry; food and drink; and cigarettes.

International trade practice is not fully executed as a theory in which all countries trade freely. In fact, each country will implement specific protection in the form of trade barriers intended to protect domestic producers from global competition. Trade barriers may include tariff and non-tariff barriers. Indonesia and Turkey impose tariff barriers and non-tariff barriers on imported products. Based on data from the World Bank (2014) the highest MFN (Most Favorable Nations) tariff imposed by Indonesia was on textile products by $7.88 \%$. Turkey itself imposes MFN tariff for imported goods. The highest MFN tariff was imposed on food products by $26.62 \%$ in 2013 .

This study aims to analyze the competitiveness and trade integration of Indonesian export commodities to Turkey at 6 digit level of HS classification and factors affecting the export and import of main commodities between Indonesia and Turkey. This study also analyzes the complementarity between Indonesia and Turkey.
Factors that will be examined in this study are GDP per capita, real exchange rate, prices, tariffs and non-tariff barriers.

\section{LITERATURE REVIEW}

A study of trade integration and dynamics of Indonesian export to the Middle East (Case Study: Turkey, Tunisia, and Morocco) using IIT and CMS was conducted. The data used was export and import data of commodities with 2-digit HS in 2006-2007. Results showed top products of Indonesian export to Turkey are palm oil, natural rubber, and synthetic textile fibers, coconut, cotton, and vinyl chloride polymers. IIT analysis showed Indonesia's trade flows for the cover fabric was twoway trade with a very strong degree of integration in which the value of export and import totaled \$ 2.1 million and $\$ 2.4$ million as well as IIT value of 92.37. Meanwhile, Indonesia significantly demonstrate the contribution as an exporter for Animal/Vegetable Fat \& Other Oils with IIT value of 0.17 . Indonesia imports $\$ 5.4$ million of Salt, Sulfur, Stone \& Plaster and only exports of $\$$ 0.35 million with a value of IIT 0.01 . This showed that the Indonesian trade association for these two products are weak integrated. Based on the results of the CMS value, total increase in exports in the period 2005-2006 reached US \$ 126.7 billion. The increase was primarily due to the boost of competitiveness effect worth US $\$ 7.224$ billion, followed by the effects of the composition of commodities valued at US $\$ 7.051$ billion. Meanwhile, the effect of import growth actually had 
a negative impact, which amounted to US \$ 14.149 billion (Oktaviani, Widyastutik, \& Novianti, 2017).

The complementarities and competitiveness of agricultural products between China and the countries of Central and Eastern Europe (CEE) were examined. Countries of Central and Eastern Europe studied were Poland, Romania, Czech Republic, Lithuania, and Bulgaria. The data used in this study was the export and import data in 2013. The methods used in this study were the RCA (Revealed Comparative Advantage), TCl (Trade complementarity Index), and IIT (Intra-Industry Trade). Results showed that Chinese export commodities included fish, fruits, vegetable products, and silk. While the top imported products were meat, junk meat edible, edible animal products such as milk, honey, and eggs. China's top export commodities were products of laborintensive industries. China and the five countries of CEE had a high complementarity in which the CEE countries more dependent on China. Trade in agricultural products between China and the five countries of CEE showed the character of inter-industry trade and intra-industry trade in which intraindustry trade was more dominant (Yu, C. \& Qi, 2015).

Arora (2015) conducted a study on the competitiveness of the Indian textile export commodities with its trading partners. The data covers 15 textile products for 12 years to 7 export destinations of India. The method used was dynamic data panel, the model estimated on the basis of each country. However, to see the development of each commodity, the study was also analyzed by each commodity by using Ordinary Least Square method. Results showed the price elasticity was negative for all Indian trading partner countries studied, except for the Chinese state. The income elasticity was positive, consistent with the hypothesis for all the countries studied. The price elasticity for all countries was less than the infinite which showed export competitive on prices. The income elasticity was less than one except for Italy which means that export to Italy was less income competitive.

The import and export demand function of Pakistan were examined by using bilateral trade data. The data used was the time series data from the years 1973-2008 and estimated by Ordinary Least Square method and Cointegration Test. Results showed GDP was important determinant of export and import. Export of Pakistan had a long-term relationship with Japan and the United States. Import of Pakistan had a long-term relationship with the UAE and the US. Import and export had long-term relationship with Sri Lanka and Bangladesh. The real exchange rate had a negative effect on the import of Pakistan with its partner countries except Bangladesh, Sri Lanka, and the UAE. Income had positive influence on import of Pakistan with its partner countries, except Sri Lanka. The real exchange rate and the income of China, Germany and the UAE did not have a Granger- 
causality relationship with Pakistan's export. The real exchange rate and the income of Pakistan had Granger causality relationship with import from Germany, India, and the UK (Haider, Afzal, \& Riaz, 2014).

The bilateral import and export demand function of Bangladesh was examined. The data used was the time series data in 1973-2009. Results showed income elasticity had positive and significant impact on export. In the contrary, the income elasticity of imports had significant and positive effect only for Germany and Hong Kong. Real exchange rate on export had significant relationship and in accordance with the theory, which is the real depreciation in the currency of Bangladesh (Taka) will cause an increase in exports. In contrast to the import side, the depreciation of Taka will increase import price to be more expensive so consumers would prefer to consume domestic products (Murad, 2012).

\section{METHOD, DATA, AND ANALYSIS}

The data used in this research was obtained from the World Development Indicators (WDI), the World Trade Organization (WTO), and International Trade Center (ITC). The trade data used are time series data in 1996-2018 at 6-digit level of HS classification.

1. Trade Complementarity Index (TCl)

$$
\begin{gathered}
C^{A B}=100\left[1-\sum_{q} \frac{\left|m_{q}^{A}-x_{q}^{B}\right|}{2}\right] \\
C^{A B} \quad \text { is } \quad \text { Trade }
\end{gathered}
$$

Complementarity Index between Turkey and Indonesia. $m_{q}^{A}$ is product $q$ 's share in Turkey's imports from the world and $x_{q}^{B}$ is its share in Indonesia's exports to the world; both should be at the HS6 level of disaggregation. The higher the index indicates the higher level of efficiency of trade between Indonesia and Turkey.

2. Revealed Comparative Advantage (RCA)

Analysis of comparative advantage (Revealed Comparative Advantage) formulated as follows:

$R C A=\frac{X p q / X p}{W p q / W p}$

$X p q$ is the value of commodity $q$ exported by Indonesia to Turkey. $X p$ is the value of total exports from Indonesia to Turkey. $W p q$ is the value of commodity $q$ exported by World to Turkey and Wp is the value of total world exports to Turkey. RCA value which is less than one indicates the commodity does not have comparative advantage. While the RCA value which is more than one indicates that the commodity has comparative advantage (Balassa, 1965).

3. Intra-Industry Trade (IIT) Bilateral intra-industry trade:

$$
\begin{gathered}
I I T_{i j}^{q}=\frac{\left(\Sigma X_{i j}^{q}+\Sigma M_{i j}^{q}\right)-\left|\Sigma X_{i j}^{q}+\Sigma M_{i j}^{q}\right|}{\left(\Sigma X_{i j}^{q}+\Sigma M_{i j}^{q}\right)} \times 100 \\
I I T_{i j}^{q} \text { denotes the intra- }
\end{gathered}
$$
industry trade of commodity $q$ between Indonesia and Turkey. $X_{i j}^{q}$ is the export value of commodity $q$ exported by Indonesia to Turkey. $M_{i j}^{q}$ is the import value of commodity $q$ imported by Turkey. $i$ is reporting country (Indonesia), $j$ is partner country (Turkey), and $q$ denotes commodity. 
Table 1. IIT Index Classification

\begin{tabular}{cl}
\hline Value of IIT Index & \multicolumn{1}{c}{ Classification } \\
\hline 0.00 & No integration; one-way trade \\
$0.00>24.99$ & Weak integration \\
$25.00-49.99$ & Mild integration \\
$50.00-74.99$ & Moderately strong integration \\
$75.00-99.99$ & Strong integration
\end{tabular}

Source: (Austria, 2004)

4. Export Demand Function Analysis of the factors affecting Indonesia's exports to Turkey carried out by analyzing time series data for each commodity which refers to research carried out by Haider et al. (2011) with some additional variables, especially tariffs and non-tariff barriers. Model specification for this analysis is $\operatorname{LnXt}=\beta 0+\beta 1 \ln ($ RGDPCTt $)+$ $\beta 2 \ln (R E X R t)+$

$\beta 3 \ln ($ EXPRICEt) + $\beta 4$ TariffTURt $+\beta 5$ DNTMTURt + $\varepsilon t$

(4)

Model is estimated by using Ordinary Least Square. $X t$ denotes the export value (US\$). RGDPCTt denotes Turkey's real GDP per capita (US\$). REXRt denotes Indonesia's Real Exchange Rate (Rp/US\$). EXPRICEt denotes real export price (US\$). TariffTURt denotes MFN tariff applied by Turkey. DNTMTUR denotes dummy non-tariff measures applied by Turkey; 1 if there is nontariff measure applied and 0 if there is no non-tariff measure applied.

\section{Import Demand Function} Model specification for import demand analysis is

Ln $M t=\alpha 0+\alpha 1 \ln (R G D P C I t)+$ $\alpha 2 \ln (R E X R t)+$ $\alpha 3 \ln ($ IMPRICEt) + $\alpha 4$ TariffINDt $+\alpha 5$ DNTMINDt + $\omega t$

(5)

Model is estimated by using Ordinary Least Square. $M_{t}$ denotes the import value (US\$). RGDPCIt denotes Indonesia's real GDP per capita (US\$). REXRt denotes Indonesia's Real Exchange Rate (Rp/US\$). IMPRICEt denotes real import price (US\$). TariffINDt denotes MFN tariff applied by Indonesia. DNTMIND denotes dummy non-tariff measures applied by Indonesia; 1 if there is non-tariff measure applied and 0 if there is no non-tariff measure applied. Expected signs for each variable are $B 1, a 1, B 2>0 ; a 2, B 3, a 3, B 4, a 4$, $B 5, a 5<0$.

\section{RESULT AND DISCUSSION}

Turkey is one of Indonesia's 30 largest export destinations (Indonesia Ministry of Industry, 2014). The top industrial products exported by Indonesia to Turkey include textiles, processing coconut/palm, rubber processing, basic chemicals, and pulp and paper. While the industrial products imported from Turkey include textiles; steel, machinery, and automotive; Basic Chemistry; food and Drink; and cigarettes. Figure 1 shows the development of Indonesia and Turkey's trade. 
The trade balance between Indonesia and Turkey in the period 2001-2018 experienced surplus except in 2008. The deficit of US\$ 346 million in 2008 happened because Indonesia experienced an overall trade deficit due to the global crisis.

Non-oil trade balance shows a rising trend and is always a surplus. However, trade balance of all commodities shows a deficit that is affected by the oil and gas sector. In 2013, the trade balance decreased sharply due to a very sharp increase in import to US\$ 1.3 billion compared with the previous year of US\$ 300 million. A sharp increase in import in 2013 was caused by imported oil and gas. Indonesian Economic Report (2013) recorded a trade deficit of oil and gas in 2013 by US\$ 9.7 billion, higher than the deficit in 2011 by US\$ 0.7 billion and US\$ 5.2 billion in 2012. The trade deficit was influenced by the high import of oil and gas sector. Oil import reached US\$ 40.4 billion in 2013, an increase over the previous year by US\$ 38.3 billion. Increased oil imports was influenced by an increase in country's fuel consumption, especially the transport sector. Increased import was also affected by declining oil production from 862 thousand barrels per day in 2012 to 827 thousand barrels per day in 2013.

Oil trade deficit was also affected by the decline in gas export. Gas exports in 2013 recorded US\$ 15.7 billion, declined by $11.2 \%$ compared to 2012. The decline in gas export was influenced by the government policy of energy conversion from oil fuel to gas fuel through the utilization of domestic gas production. Although it caused the decline in gas export, the policy on the other hand was able to prevent a higher increase in oil import.

Figure 1 Trade Balance Growth

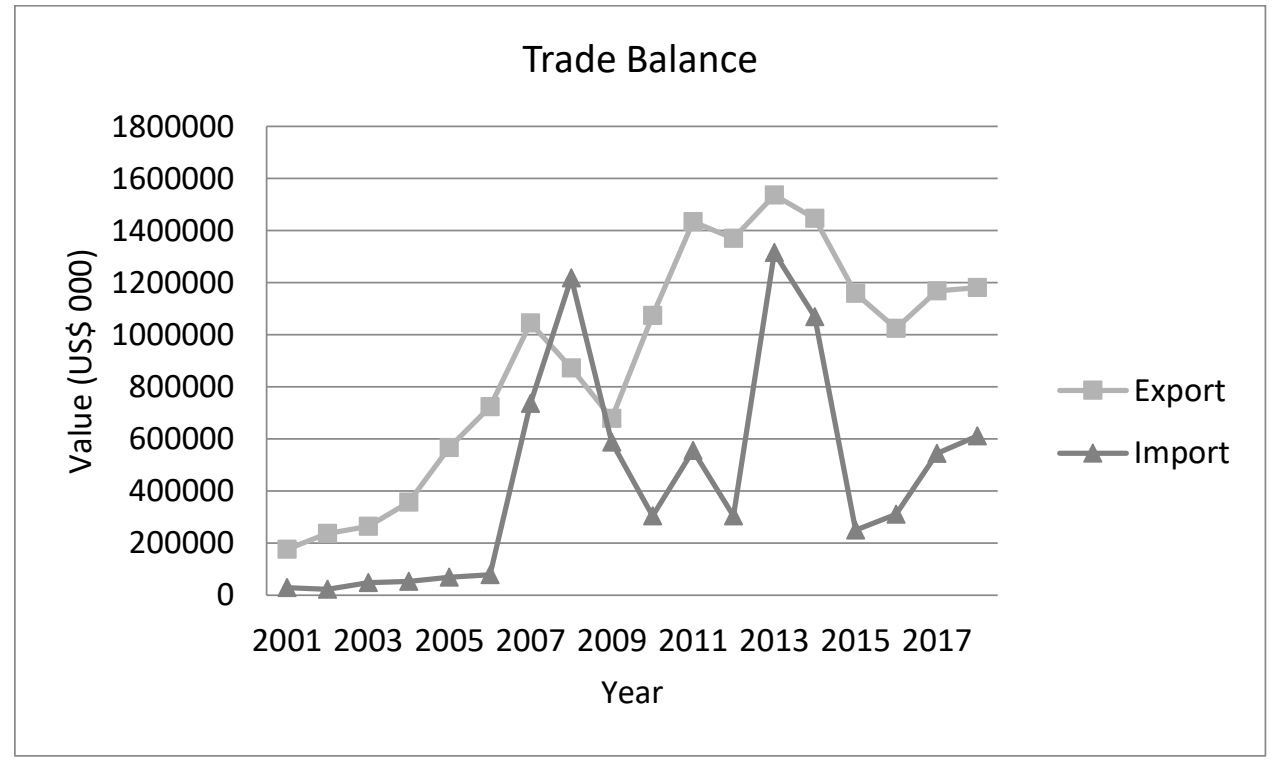

Source: ITC Trademap (2018) 
Trade Complementarity Indexes between Indonesia and Turkey

$\mathrm{TCl}$ values range between 0 -

100. A value of 0 indicates no complementarity which means that these countries are competitors, while 100 indicates that the trade of these countries are complementary.

Figure 2 shows the $\mathrm{TCl}$ values of Indonesia and Turkey from 2001 to 2018. The results show the value of $\mathrm{TCl}$ ranges between 17-30. The highest $\mathrm{TCl}$ value is 29.64874 which occurs in 2001. Then the number decreases in the following years. Then the lowest value occurs in 2008 at 17.29052 and a slight increase in the following year until 2018. These low $\mathrm{TCl}$ values indicate low complementarity between Indonesia's export and Turkey's import. Turkey is not Indonesia's main export destination. Judging from Indonesia's exports to the world, the share of Indonesia's exports to Turkey is only $0.8 \%$. Despite its low $\mathrm{TCl}$ values and low export share, Turkey can be used as a stepping stone for Indonesian export products in order to penetrate the market in European Union (EU) as well as the market in Central Asia countries such as Uzbekistan, Azerbaijan, Kazakhstan and Turkmenistan. Indonesia's main export destinations include Japan, China, America, Singapore, and India. Similarly, to Turkey, Indonesia is not its main importing country. Turkey's main importing countries are Russia, China, Germany, and Italy.

Figure $2 \mathrm{TCl}$ Value Growth

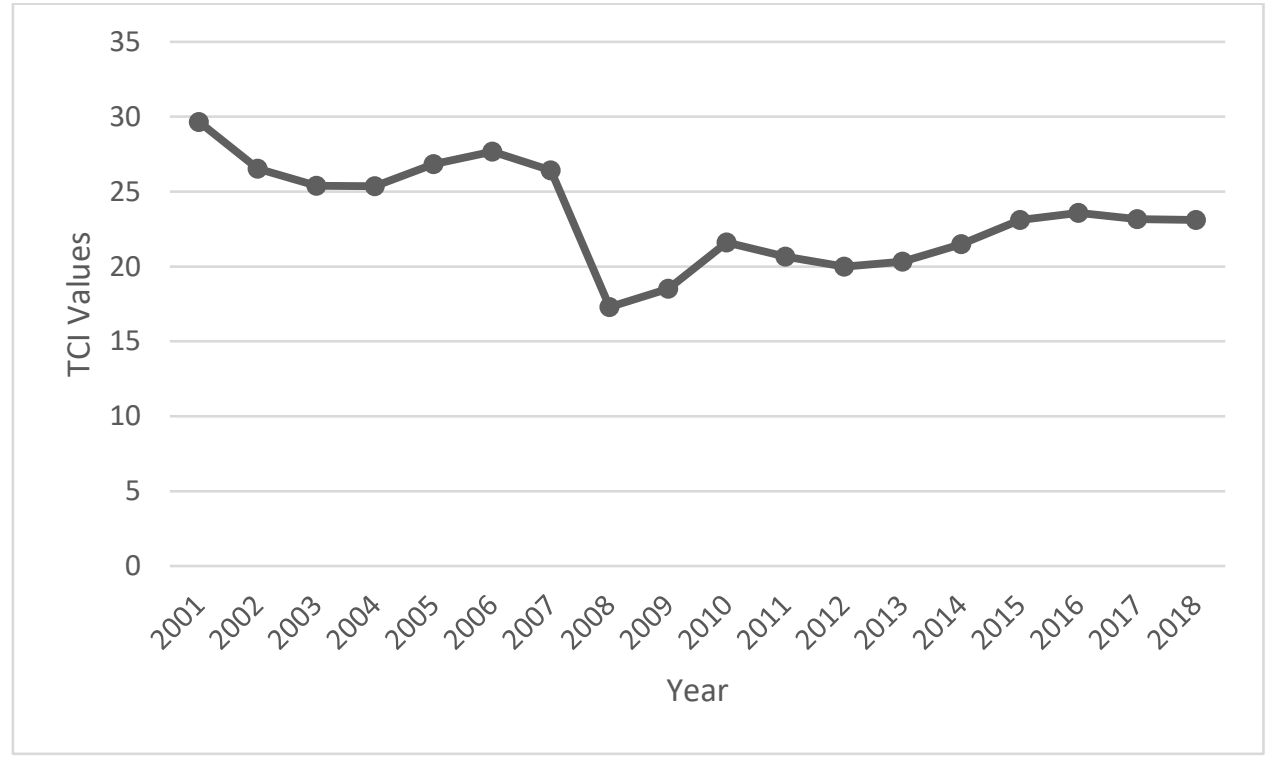

Indonesian Main Export Commodities to Turkey

Indonesian main export commodities to Turkey are selected based on the high share in Turkish imports and have RCA value of more than 1 indicating the comparative advantages. Some commodities selected in this study are consistent with results of research conducted by Oktaviani, et al. (2009). The study mentioned some export 
commodities from Indonesia to Turkey which were palm oil, natural rubber, synthetic textile fibers, coconut, cotton, and vinyl chloride polymers.

Table 2. Indonesian Main Export Commodities to Turkey

\begin{tabular}{|c|c|c|c|c|}
\hline \multicolumn{5}{|c|}{ Manufacture } \\
\hline HS Code & Product Label & $\begin{array}{c}\text { Share in Turkish } \\
\text { Import }(\%)\end{array}$ & $\begin{array}{c}\text { Average } \\
\text { RCA }\end{array}$ & IIT \\
\hline 551611 & $\begin{array}{l}\text { Woven fabrics,containg }>/=85 \% \text { of } \\
\text { artificial woven fabrics, unbleached/bl }\end{array}$ & 85.5 & 67.4328 & 0 \\
\hline 382311 & Stearic acid & 72.2 & 74.9525 & 0 \\
\hline \multicolumn{5}{|c|}{ Agriculture } \\
\hline HS Code & Product Label & $\begin{array}{c}\text { Share in Turkish } \\
\text { Import }(\%)\end{array}$ & $\begin{array}{c}\text { Average } \\
\text { RCA }\end{array}$ & IIT \\
\hline 400122 & $\begin{array}{l}\text { Technically specified natural rubber } \\
\text { (TSNR) }\end{array}$ & 66.2 & 77.4394 & 0 \\
\hline 151190 & $\begin{array}{l}\text { Palm oil and its fractions refined but not } \\
\text { chemically modified }\end{array}$ & 64.7 & 69.6719 & 0 \\
\hline
\end{tabular}

1. Woven fabrics (HS 551611)

The export value of woven fabrics (HS 551611) from Indonesia to the world in 2014 is US\$ 50.5 million with $9 \%$ growth and the share in world's export is $13.7 \%$. Woven fabrics export value from Indonesia to Turkey worth US\$ 26 million. The growth of woven fabrics export from Indonesia to Turkey in 2001-2018 is shown in Figure 3. This commodity has a market share of $85.5 \%$ on Turkish import which means that most of the commodity is imported from Indonesia. Other exporter countries of this commodity to Turkey are China, Malaysia, Korea and Thailand. In addition, Indonesia also exports this commodity to other countries such as Japan, Thailand, United Arab Emirates, Spain, and Germany.

Figure 3 Growth of Woven Fabrics Export

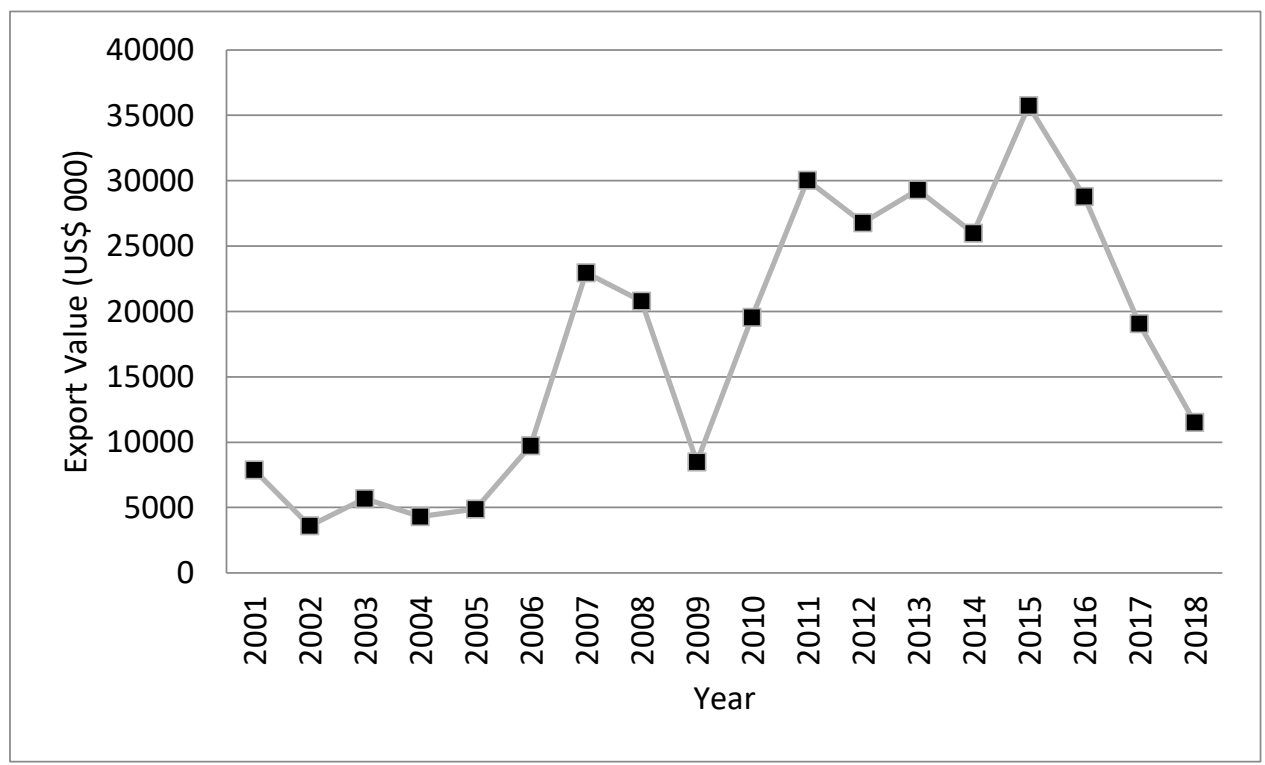


Average RCA value in 20012018 is 67.4328 , which means this commodity has comparative advantage. RCA value growth of the year 2001-2018 is shown in Figure 4. In 2001, the RCA value reaches 85.1905 then declines in the following year to 40.3754 , this is due to an increase in the export of woven fabrics to Turkey from other countries such as Malaysia, Thailand, and UK. The fluctuation of RCA values is affected by increases and decreases in export value from other Turkey's exporter countries. The highest number occurs in 2008 which reaches 104.2042. In 2008, the share of woven fabrics reaches $93 \%$ from the total value imported by Turkey from the world. RCA in the following year (2009-2014), ranges between 51-62. This is due to increasing in export from other countries to Turkey mainly from Malaysia and China.

IIT development in 2001-2018 shows a constant number 0 , which means there is only one-way trade from Indonesia. However, in 2012 IIT reaches 0.00747 indicating weak integration, this is because Indonesia imported the same commodity from Turkey worth US\$ 1 thousand.

Figure 4 Growth of Woven Fabrics RCA

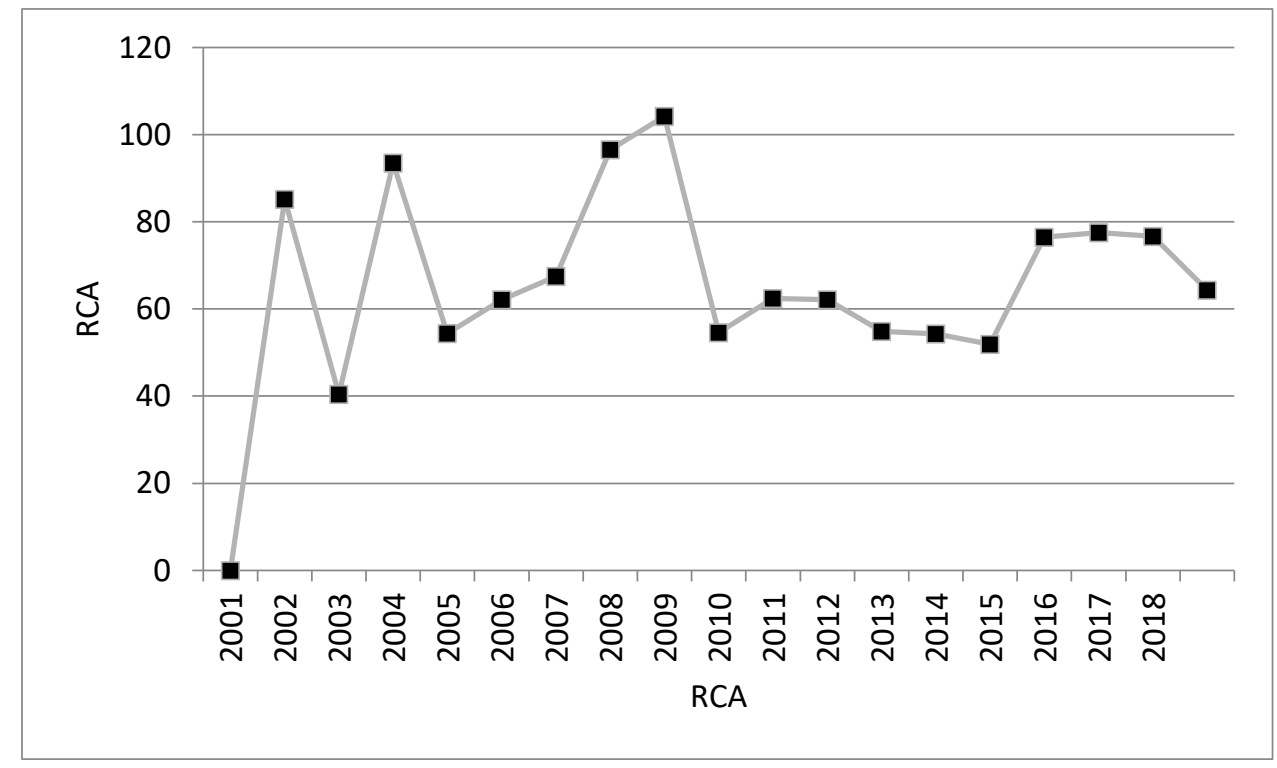

2. Stearic Acid (HS 382311)

Stearic acid export from Indonesia to the world is worth US\$ 440 million, with $15 \%$ growth and the share in world's export is $39.5 \%$. Export value of stearic acid from Indonesia to Turkey is worth US\$ 8.9 million. The development of stearic acid export from Indonesia to Turkey in 2001-2018 is shown in Figure 5. The growth of export of stearic acid is in increasing trend. Figure 5 shows the highest export value in 2012 at US\$ 38 million. Stearic acid (HS 382311) has $72.2 \%$ market share in 2014, which means that Turkey imports most of the commodity from Indonesia. Turkey imports the rest 
from Malaysia, Italy, Belgium, and Germany. While Indonesia is also exporting this commodity to China, Korea, and the Netherlands.

Figure 5 Growth of Stearic Acid Export

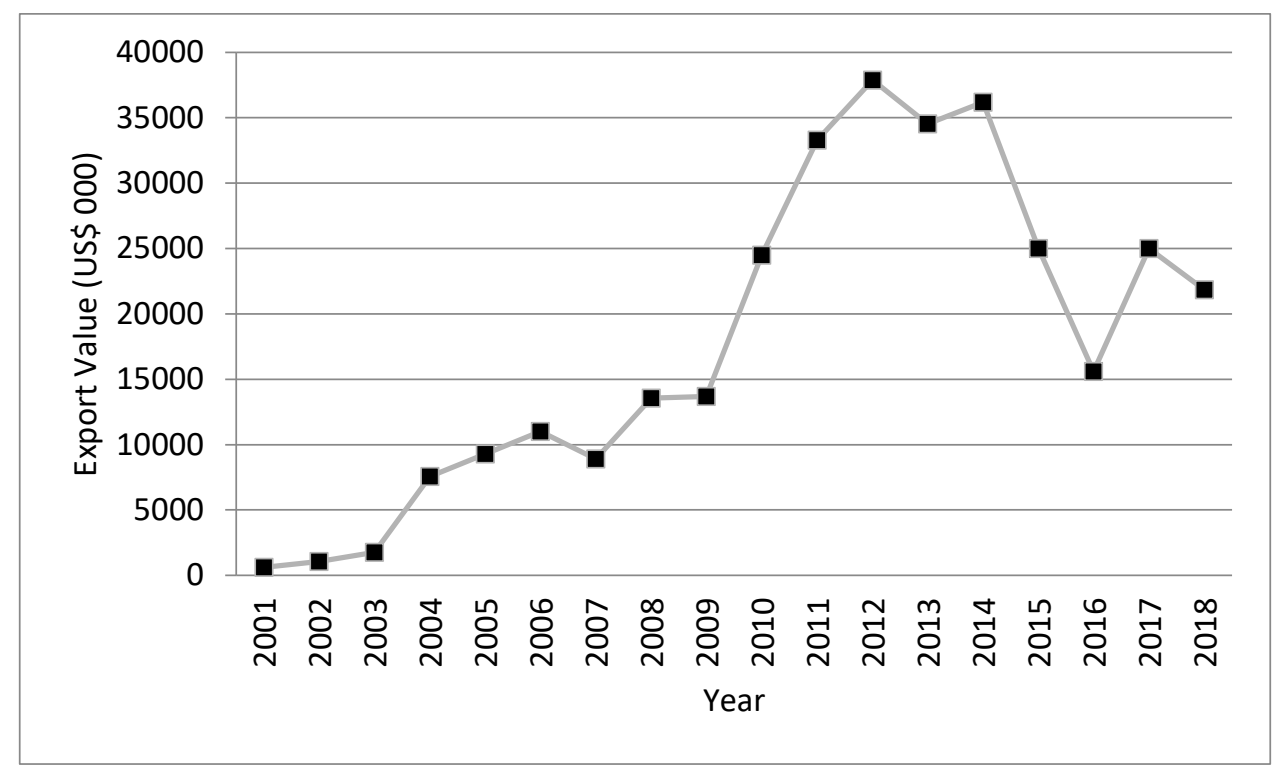

Average RCA value of stearic acid in 2001-2018 is 74.9525 which means it has comparative advantage. Figure 6 shows RCA value growth. In 2001, RCA value reaches 22.1205. Export value from Indonesia to Turkey is still smaller than the export value from Malaysia to Turkey from 2001-2003. During 2001-2003, the share of import from Malaysia reaches $50 \%$, while Indonesia is only about $16-20 \%$. An increase occurs in 2004 to 106.5372 due to increased export from Indonesia with 52\% market share, while Malaysia's market share is $39 \%$. The lowest value of RCA occurs in 2007, it reaches 38.4389 with $28 \%$ market share, while Malaysia reaches 40\%, followed by a significant increase in import from other countries such as China, Italy, and Australia. RCA value in subsequent years increases until reach 102.3270 in 2014 where the share of import from Indonesia reaches $72 \%$, while about $22 \%$ of Malaysia and the rest is from other countries. IIT indicates there is only one-way trade from Indonesia. 
Figure 6 Growth of Stearic Acid RCA

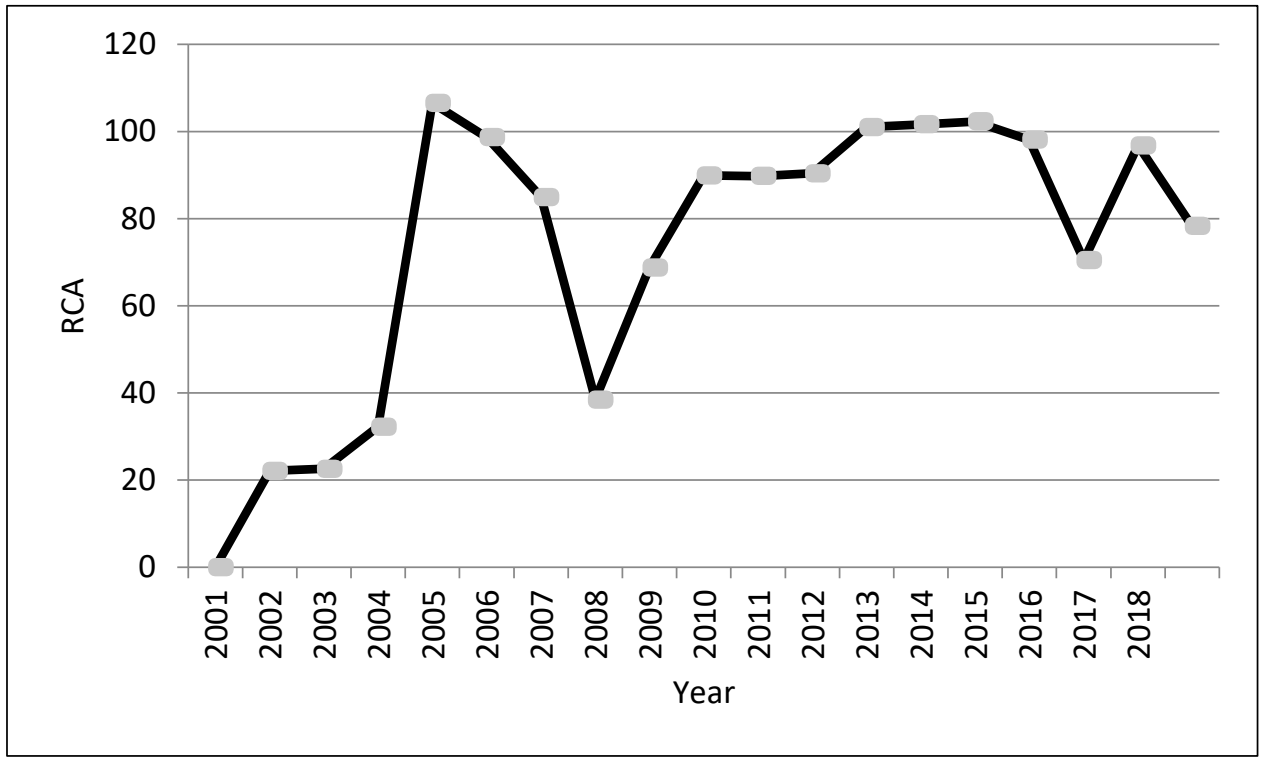

3. Natural Rubber (HS 400122)

The export value of natural rubber (HS 400122) from Indonesia to the world is worth US\$ 7.1 billion in 2010 and US\$ 4.6 billion in 2014 with an average growth of $-13 \%$. Market share in the world's export is $39.5 \%$. The export value of natural rubber from Indonesia to Turkey has an increasing trend. The highest export value in 2011 reaches US\$ 303 million. However, these export decreased in the following years until in 2014 the export value reaches US\$ 127 million. The growth of natural rubber export from Indonesia to Turkey in 2001-2018 can be seen in Figure 7.

Figure 7 Growth of Natural Rubber Export

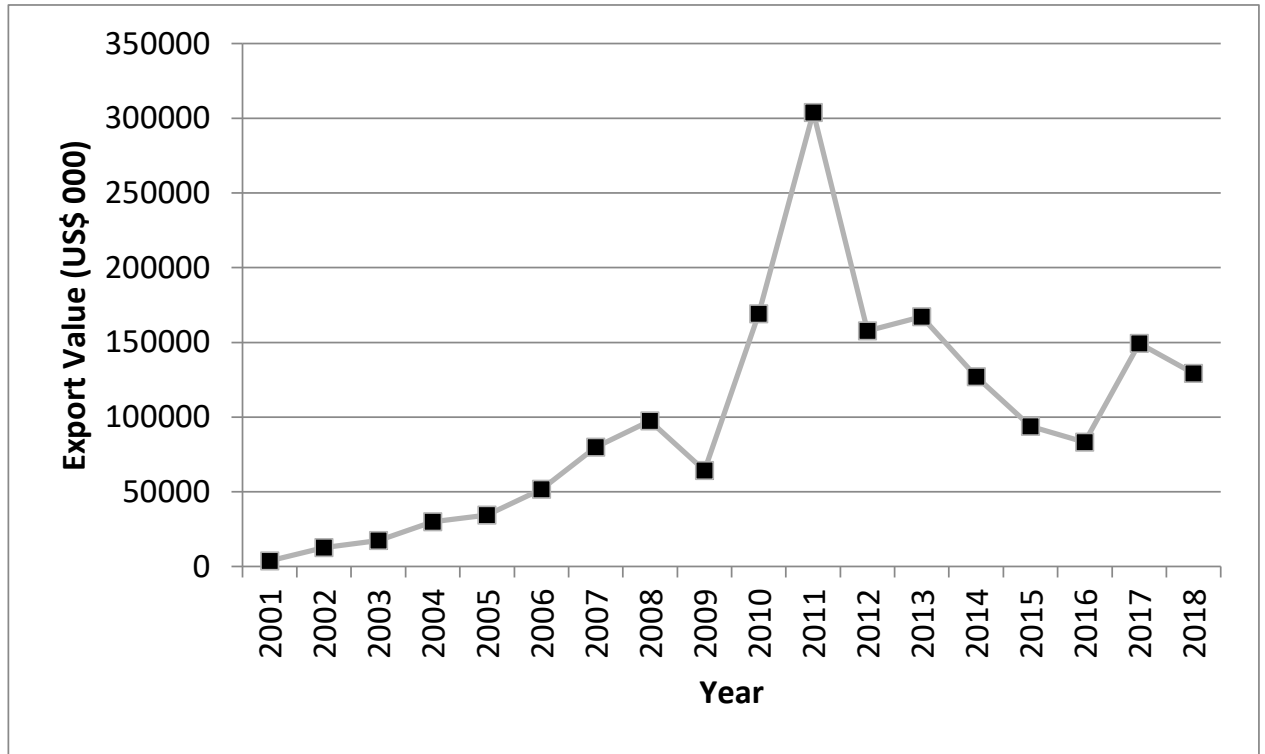


TSNR or natural rubber is one of the main export commodities from Indonesia to Turkey. It can be seen from the average RCA value in 2001-2018 which reaches 77.4394. The growth of natural rubber RCA values is shown in Figure 8. RCA value in 2001 is 26.1204 with $16 \%$ market share, while Malaysia by $44 \%$, and Thailand by $27 \%$. RCA value growth of natural rubber increases, until in 2014 it reaches 93.3846 with $66.2 \%$ market share, while Thailand reaches $13 \%$ and Malaysia reaches $10 \%$.

Figure 8 Growth of Natural Rubber RCA

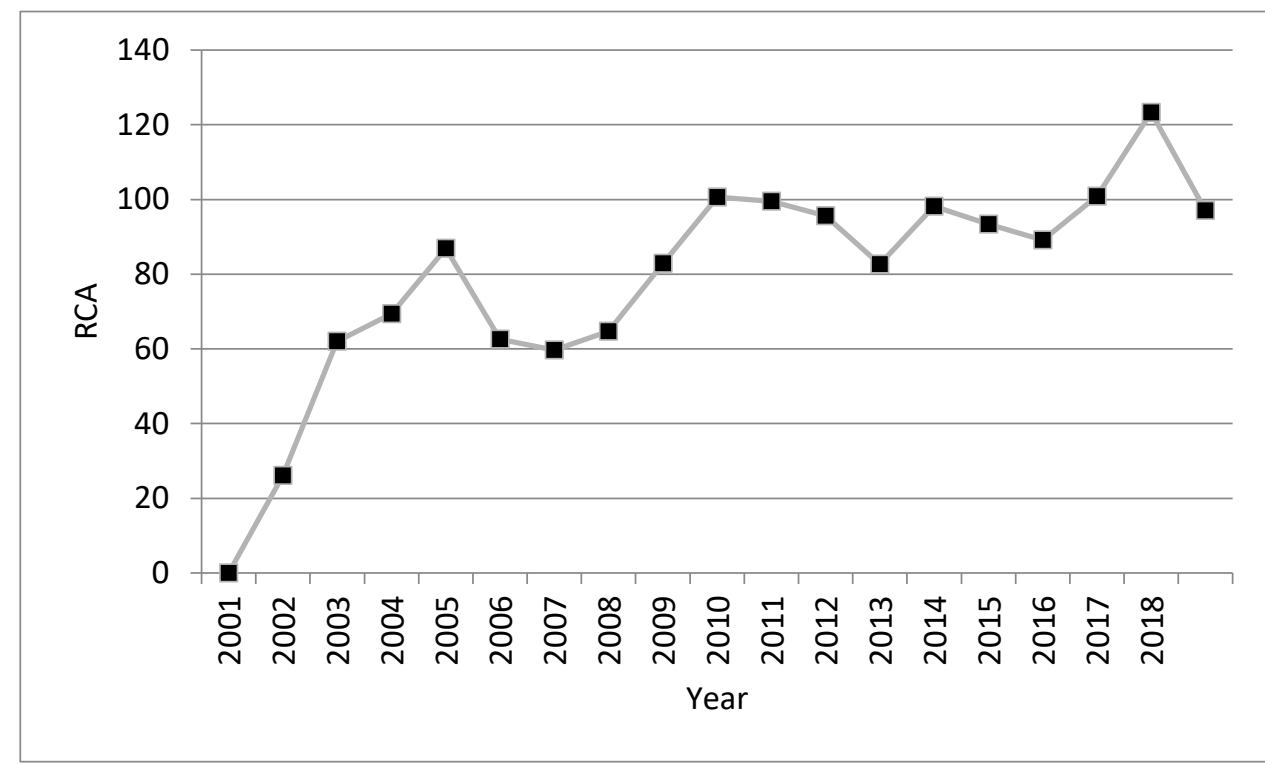

One-way trade from Indonesia is indicated by IIT value of 0 . Additionally, TSNR is an important export commodity. Turkey imports most of these commodities from Indonesia, as shown by the market share by $66.2 \%$. Turkey also imports the commodity from other countries such as Thailand, Malaysia, and Vietnam. As for Indonesia, Turkey is the 9th export destination for natural rubber after US, Japan, China, India, Korea, Brazil, Canada, and Germany.

\section{Palm Oil}

The export value of palm oil (HS 151190) to the world is US\$ 5.8 billion in 2010 and US\$ 13.2 billion in 2014, average growth from 20102018 by $21 \%$ and the share in world's export reaches $54.1 \%$. The export value of palm oil from Indonesia to Turkey is US\$ 152 million in 2014. In terms of export growth, the export value of palm oil from Indonesia to Turkey tends to fluctuate. The lowest export value occures in 2004 at US\$ 20 million, then there is a sharp increase in 2007 worth US\$ 172 million. In 2009 it drops by nearly US\$ 40 million. In 2013 it reaches US\$ 215 million. Palm oil is one of top 10 Indonesian export commodities. Turkey became one of the countries that imports palm oil from Indonesia. The share of palm oil (HS 151190) of Indonesia on Turkish imports is $64.7 \%$, which shows most of these commodities are imported from Indonesia. Turkey 
imports most of palm oil from Indonesia and from other countries such as Malaysia, Netherlands, and
Sweden. The growth of the palm oil export from Indonesia to Turkey can be seen in Figure 9.

Figure 9 Growth of Palm Oil Export

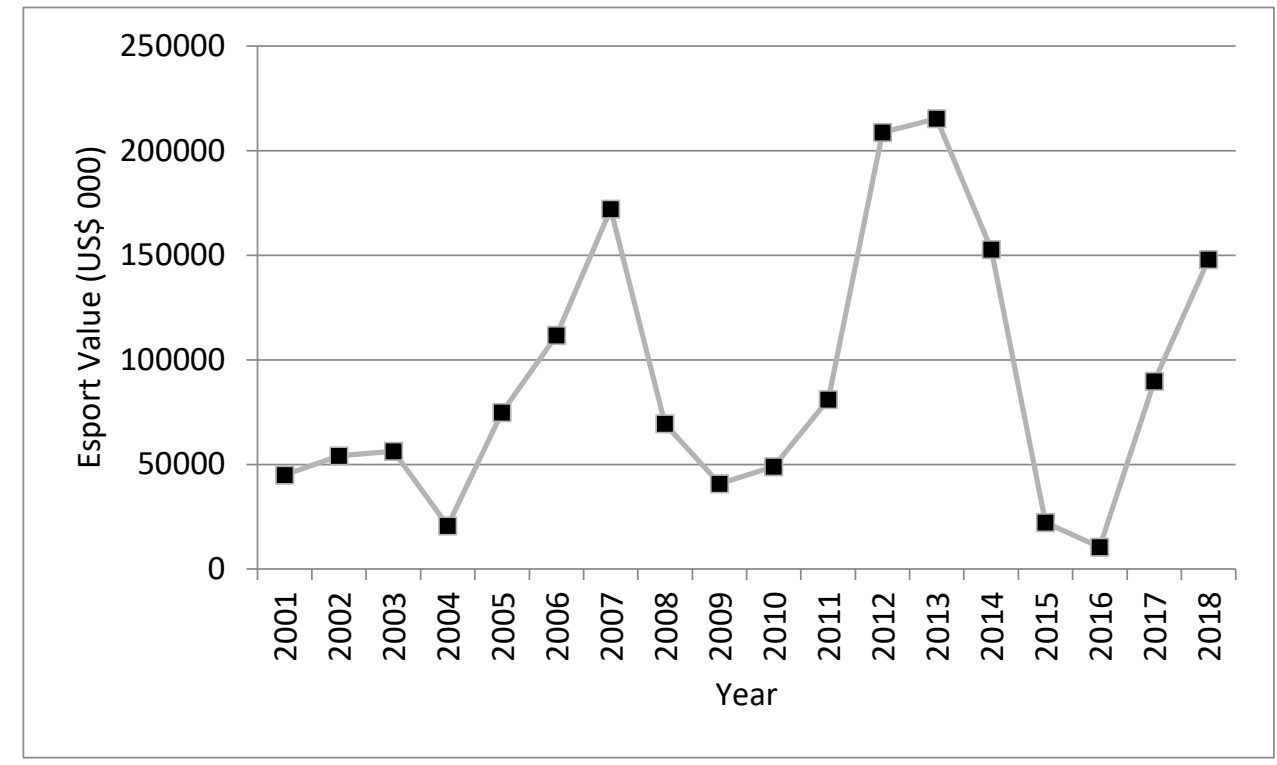

RCA value by an average of 69.6719 indicates that this commodity has a comparative advantage. The growth of palm oil RCA value is shown in Figure 10. In 2001, the value reaches 131.0564 with 54\% Indonesia's market share and $44 \%$ Malaysia's. There is a decrease in 2004 by 30.9156 with 41\% Indonesia's market share and 59\% Malaysia's. In 2007, RCA increases to 107.7597 with $56 \%$ Indonesia's market share and
Malaysia's by $44 \%$. The lowest value of RCA which is 26.5942 occurs in 2010 with $36 \%$ market share. RCA value increases in 2012 with 54\% market share and in 2014 reaches 52.0686 with $64.7 \%$ market share, followed by an increase in import of palm oil from other countries such as Malaysia, Netherlands, Singapore, Sweden, and Belgium. IIT value indicates that trade only occurs in one direction from Indonesia. 
Figure 10 Growth of Palm Oil RCA

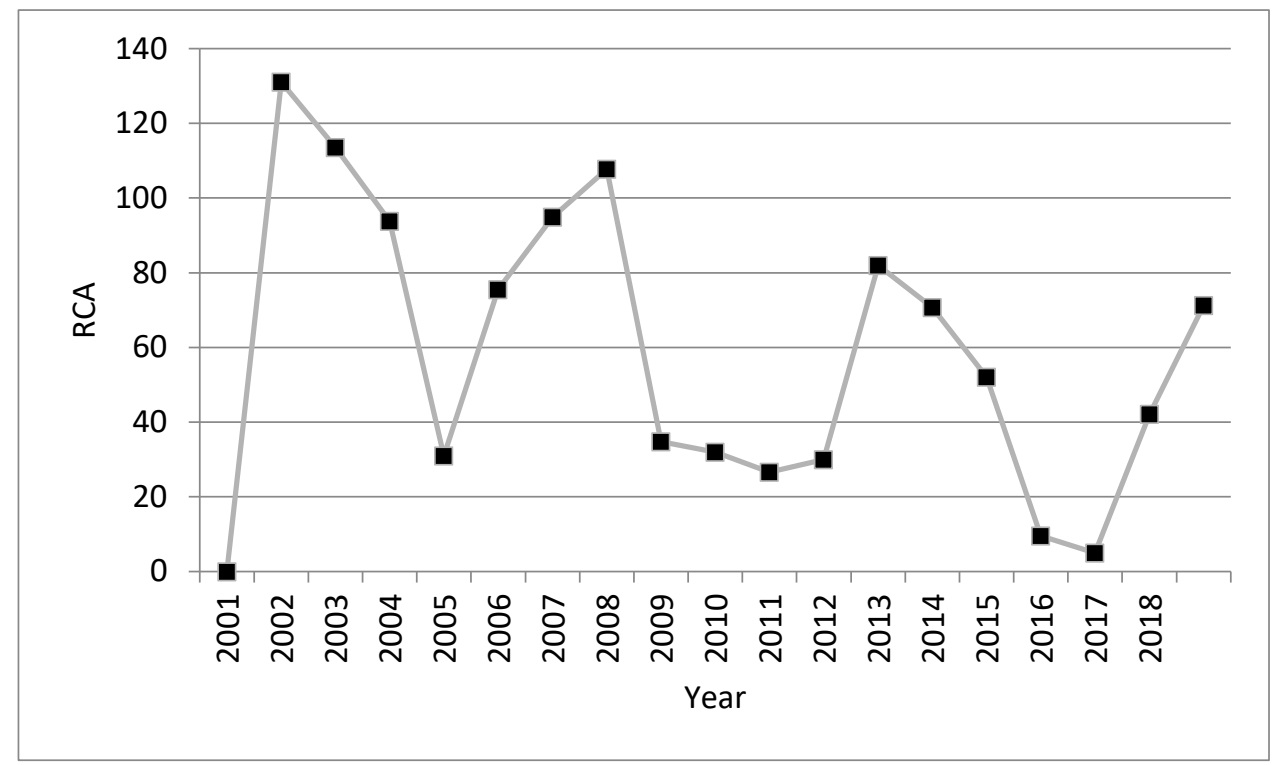

Indonesian Import Commodities from Turkey

The selection of import commodities in this study is based on the high import value and high share in Indonesian import. Table 3 shows Indonesian import commodities from Turkey. Chosen manufacture commodities are carpets and borax while chosen agriculture commodities are wheat flour and tobacco. The chosen commodities do not have high market shares except carpets. It shows that Turkey is not a major exporting country for these commodities. So the chosen commodities are those which market share is relatively high compared to other

Table 3. Indonesian Import Commodities from Turkey

\begin{tabular}{|c|c|c|c|}
\hline $\begin{array}{l}\text { HS } \\
\text { Code }\end{array}$ & Product Label & $\begin{array}{l}\text { Import Value in } 2014 \\
\text { (US\$ thousand) }\end{array}$ & $\begin{array}{c}\text { Share in } \\
\text { Indonesian Import } \\
(\%)\end{array}$ \\
\hline \multicolumn{4}{|c|}{ Manufacture } \\
\hline 570242 & $\begin{array}{l}\text { Carpets of man-made textile mat,of } \\
\text { woven pile construction,made up,nes }\end{array}$ & 2492 & 67 \\
\hline 284019 & $\begin{array}{l}\text { Disodium tetraborate (refined borax) } \\
\text { hydrated }\end{array}$ & 15216 & 37.8 \\
\hline \multicolumn{4}{|c|}{ Agriculture } \\
\hline \multirow{2}{*}{$\begin{array}{l}110100 \\
240110\end{array}$} & Wheat or meslin flour & 25728 & 34.6 \\
\hline & $\begin{array}{l}\text { Tobacco, unmanufactured, not } \\
\text { stemmed or stripped }\end{array}$ & 26518 & 13.4 \\
\hline
\end{tabular}


1. Carpets (HS 570242)

Carpets is one of the top Indonesian import commodities from Turkey. The import value of carpets (HS 570242) which is imported by Indonesia from the world is US\$ 3,717 million. Indonesia imports most of carpets (HS 570242) from Turkey that is worth US\$ 2,492 million with the import growth between 2010 to 2014 is $113 \%$. While importing the rest from other countries, including Belgium, China, Egypt, Malaysia and Saudi Arabia.

Indonesia is not the main export destination of Turkish carpets. Export value of Turkish carpets to the world is US\$ 1.919 billion. Turkey's main export destinations of carpets are Saudi Arabia, USA, Iraq, Libya, and Germany. The growth of carpets import from Turkey to Indonesia can be seen in Figure 11 . The development of carpets import from Turkey in 2001-2012 is likely to increase even though the increases are not sharp. However, in 2013 there is an increase of import by US\$ 2 million that were previously only US\$ 400 thousand.

Figure 11 Growth of Carpets Import

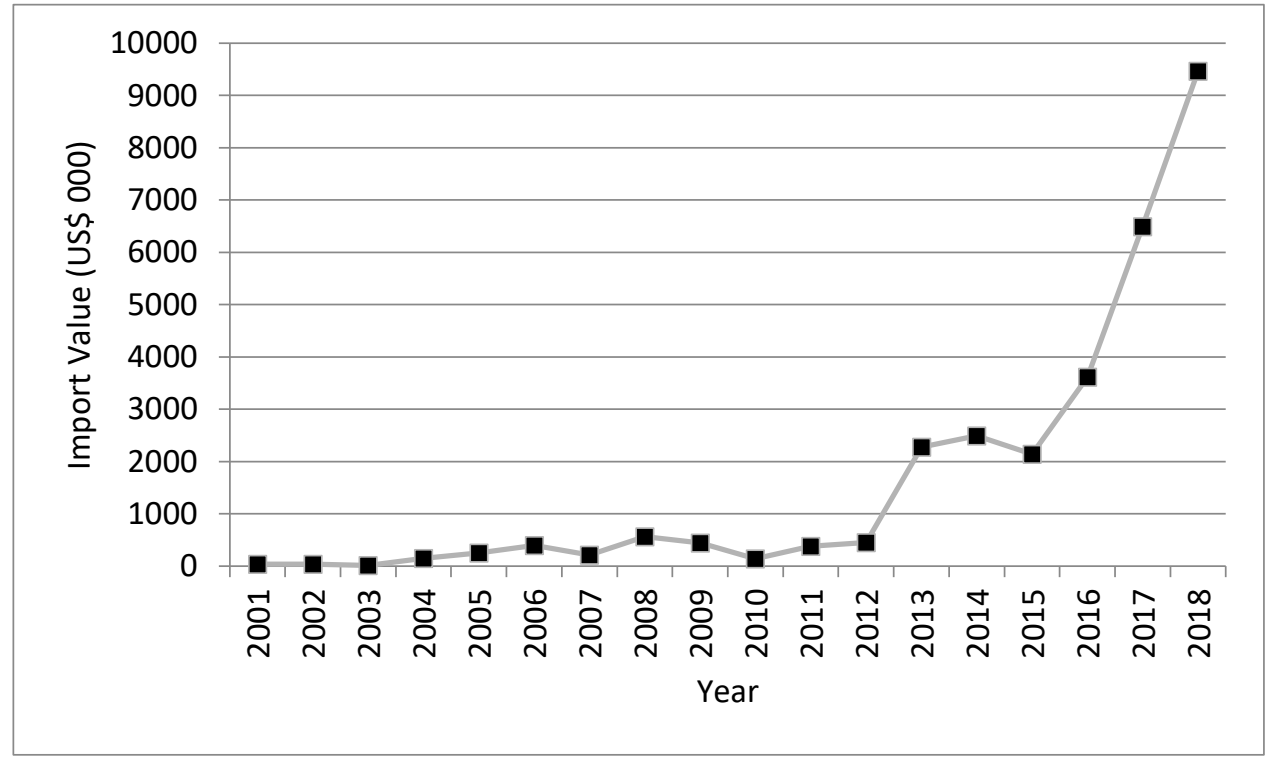

2. Borax (HS 284019)

Indonesia imports borax (HS 284019) from the world worth US\$ 40.222 million. Indonesia imports $37.8 \%$ borax from Turkey worth US\$ 15.216 million. The growth of borax imported from Turkey to Indonesia can be seen in Figure 12. Import of borax from Turkey during the period 2001-2018 is likely to increase despite a significant decrease in 2009 and 2013. The highest borax import value occurs in 2012 that is worth US\$ 16 million.

Indonesia imports most of borax (HS 284019) from the United States, Turkey, Malaysia, China, and Chile. While Turkey exports this commodity to Belgium, China, 
Indonesia, Malaysia, Netherlands, and Germany.

Figure 12 Growth of Borax Import

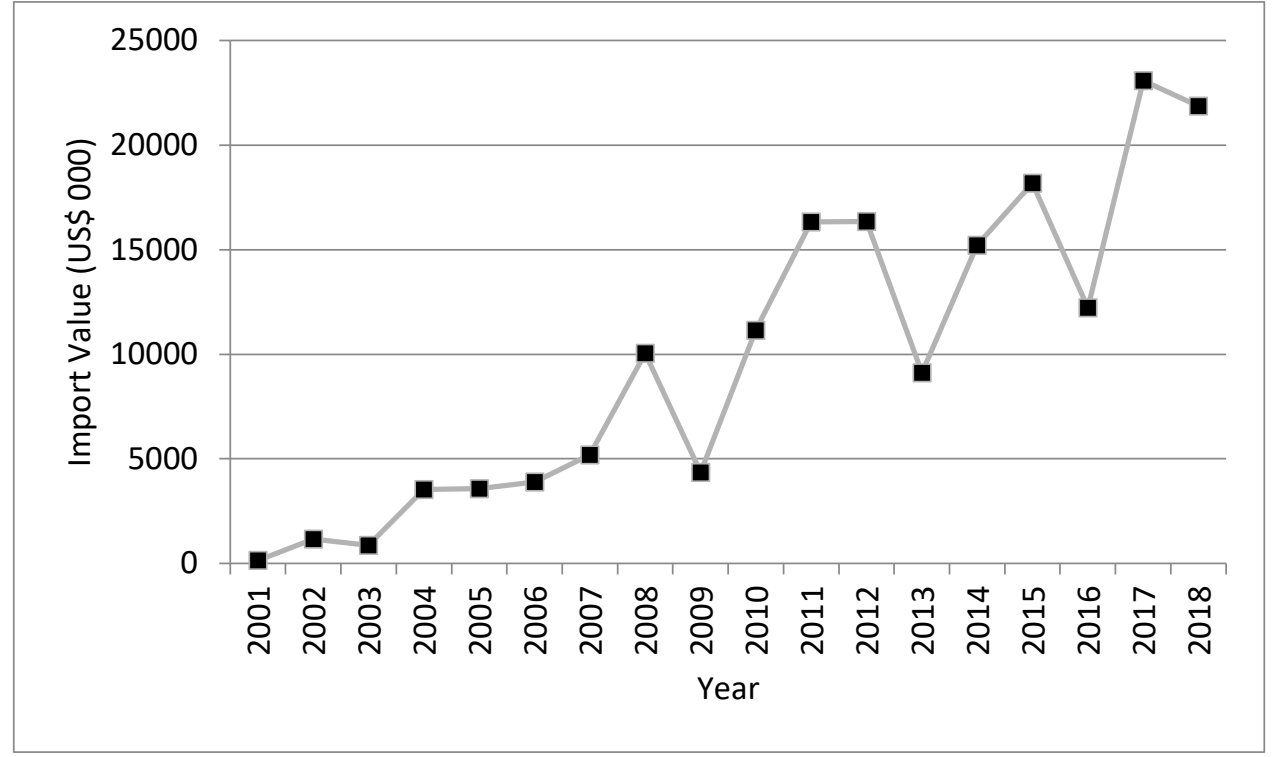

3. Wheat Flour (HS 110100)

Indonesia imports wheat flour (HS 110100) from the world worth US\$ 359 million with $-31 \%$ growth during 2010-2014. While import by Indonesia from Turkey is worth US\$ 25.728 million with $-41 \%$ growth. Indonesia imports $34.6 \%$ of wheat flour from Turkey and imports the rest from India, Sri Lanka, Ukraine, Malaysia.
To Turkey, Indonesia is the 7th wheat flour export destination. The export value of wheat flour from Turkey to the world is US\$ 932.593 million. Turkey exports this commodity to other countries such as Iraq, Syria, the Philippines, Angola, and Sudan. The growth of wheat flour imported by Indonesia from Turkey can be seen in Figure 13. 
Figure 13 Growth of Wheat Flour Import

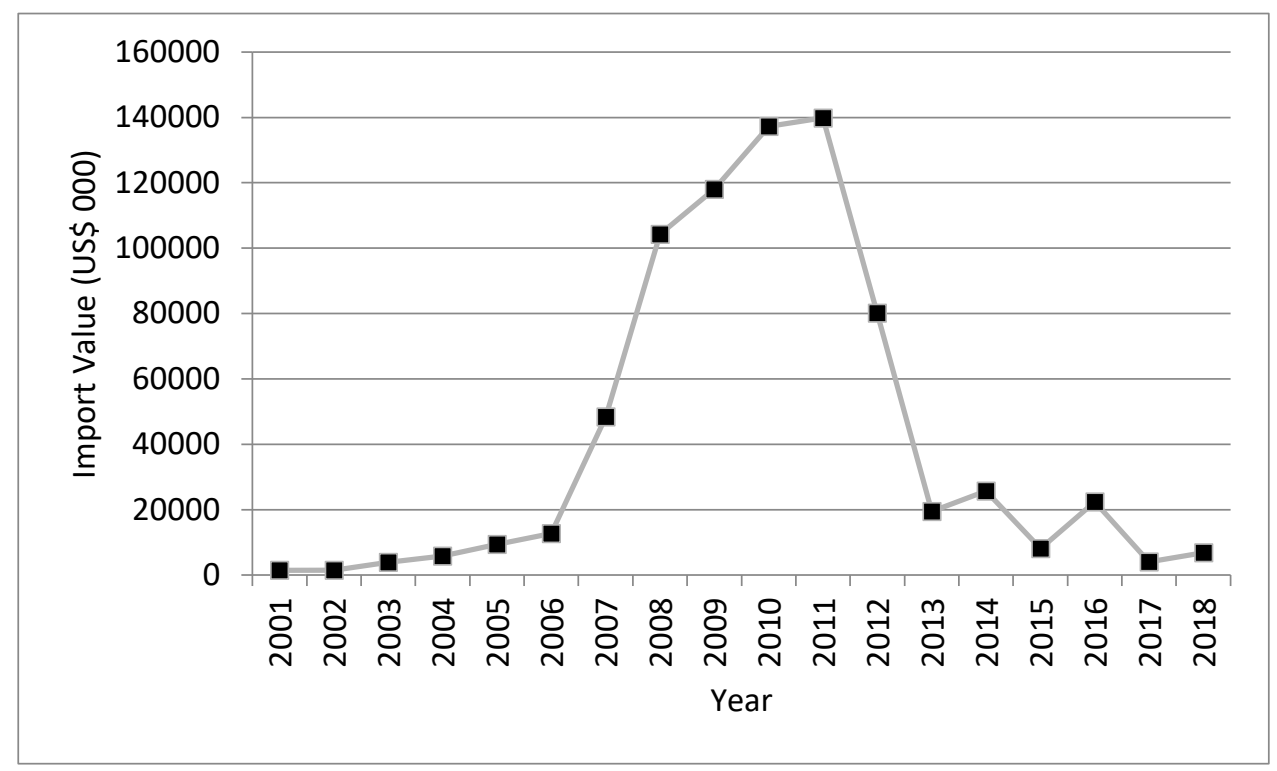

4. Tobacco (HS 240110)

Indonesia imports tobacco

(HS 240110) from the world worth US\$ 197.824 million in 2014 with 25\% growth between 2010-2014. Indonesia imports tobacco (HS 240110) from China, Turkey, Italy, Brazil, Laos, and Greece. A total of $13.4 \%$ of tobacco imported from Turkey. Import by Indonesia from Turkey worth US\$ 26.518 million with $7 \%$ growth. The growth of tobacco import from Turkey to Indonesia can be seen in Figure 14.
Import of tobacco from Turkey has an upward trend from the year 20012014. Tobacco import value is the highest in 2014. Then the value tends to decrease from 2015 forward and down to the lowest value in 2018.

Turkey exports tobacco (HS 240110) to the world worth US\$ 515.538 million. Beside exporting to Indonesia, Turkey exports most tobacco to America, Belgium, Indonesia, Russia, the Netherlands, and Germany.

Figure 14 Growth of Tobacco Import

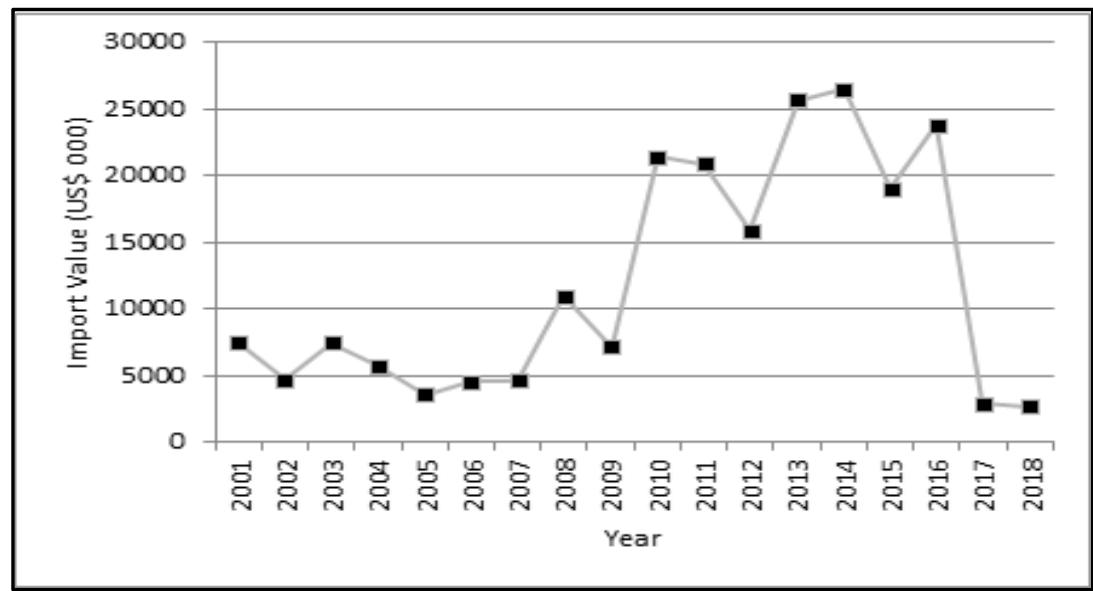


Factors Affecting Indonesian Export to Turkey

Factors affecting Indonesian export are determined by estimating regression towards each export commodity studied. The regression results are shown in Table 4.

Table 4. Regression Results of Indonesian Export Commodities

\begin{tabular}{lllll}
\hline \multicolumn{1}{r}{ Variable } & \multicolumn{1}{c}{ Woven fabrics } & \multicolumn{1}{c}{ Stearat Acid } & \multicolumn{1}{c}{$\begin{array}{r}\text { Natural } \\
\text { Rubber }\end{array}$} & \multicolumn{1}{c}{ Palm Oil } \\
\hline Ln_RGDPCT & $0.804607 * *$ & $1.793711^{* *}$ & $0.669959^{*}$ & $0.956980^{*}$ \\
Ln_Rexr & $1.272358^{* *}$ & $0.759657^{* *}$ & $0.545166^{*}$ & $0.712846^{*}$ \\
Ln_Exprice & $-0.173232^{* *}$ & $-1.503157^{*}$ & $-1.728636^{*}$ & $-0.428905^{*}$ \\
TariffTur & $-1.328691^{*}$ & $-1.171707^{*}$ & - & $-0.057786^{*}$ \\
DNTMTUR & $-1.490706^{* *}$ & $-0.433110^{* *}$ & $-0.277823^{*}$ & $-0.115273^{* *}$ \\
C & $10.24071^{* *}$ & $25.99349^{* *}$ & $25.00191^{*}$ & $27.93971^{*}$ \\
Rsquared & 0.831202 & 0.987915 & 0.999918 & 0.999998 \\
\hline
\end{tabular}

$\left({ }^{*}\right)$ significant at $5 \%$

$\left({ }^{* *}\right)$ significant at $10 \%$

1. GDP per Capita

Real GDP per capita (Ln_RGDPCT) shows the level of prosperity or living standard of a country. Results show that the GDP per capita of Turkey provide a positive and significant impact on export in each commodity studied. These results are consistent with the expected sign. When the level of welfare increases, demand for export will increase as well. GDP per capita indicates the level of welfare. These results are consistent with studies conducted by Haider, et al. (2011) and Murad (2012). GDP indicates the purchasing power. GDP will be a positive influence on trade flows in terms of export because this GDP measures the magnitude of the demand.

\section{Real Exchange Rate}

The real exchange rate (Ln_Rexr) shows positive and significant impact on export commodities. The relationship indicated by the real exchange rate is consistent with the expected sign. Rising real exchange rate shows a depreciation of the rupiah so it will increase export. This is according to research conducted by Haider, et al. (2011) and Murad (2012) which showed that the depreciation of the currency will increase export. Depreciation of the currency benefits domestic sellers and foreign buyers because it makes domestic goods cheaper for foreign buyers.

3. Export price Export price (Ln_Exprice) has negative and significant effect on the export of each commodity studied. The relationship indicated by the export price is consistent with the expected sign. This is in accordance with the law of supply and demand stating that the price increase will increase the offer which has lowered demand. This also applies to the export and import between countries. Higher export price leads to the decline of demand for a country's export. A country 
tends to trade with countries that have lower export price, thereby increasing demand for a country's export.

Price elasticity ranged between 0.43-1.73 with a negative sign. This means an increase in price can lower export. Judging from the price elasticity, Woven fabrics and palm oil are inelastic commodities because the elasticities which are less than one. While stearic acid and natural rubber are elastic commodities.

Price elasticity is in line with the research conducted by Arora (2015). The value of the price elasticity shows that stearic acid and rubber are less price competitive when compared with other commodities, this is due to a change in price will lead to greater change in export value. Whereas in other commodities, change in the price causes smaller change in the export value than the price change. Woven fabrics has the smallest elasticity among other commodities, therefore woven fabrics is the most competitive commodity among other commodities.

\section{Tariff Barriers}

Tariff (TariffTUR) imposed by Turkey on products imported from Indonesia had a negative impact and significant to each commodity studied except on natural rubber commodity. These results are consistent with the expected sign. Tariffs applied by a country make imported goods become more expensive and therefore reduce the demand for export.

Turkey applies ad valorem tariff barrier on woven fabrics at
$10.1 \%$ in 1996 to 1997 and then decreased in 1998 to $9.8 \%$ and continued to be reduced by $8.0 \%$ from 2004 to 2014. Stearic acid tariff is $7.0 \%$ in 1996 and continue to decline up to $5.1 \%$ in 2001-2014. Turkey does not apply tariff on natural rubber. Palm oil subjected to tariffs of $8.0 \%$ in $1996-2003$ and then increased to $19.5 \%$ in 2004 and $24.9 \%$ in 2014.

\section{Non-Tariff Barriers}

Dummy non-tariff barriers (DNTMTUR) applied by Turkey gives negative and significant impact on the commodities studied. These results are consistent with the expected sign. Krugman and Obstfeld (2004) states that the practice of import restrictions always increase the price of imported goods in the domestic market. If imports are restricted, a direct result is that at the level of the original price (before limitation) the demand for the goods is greater than domestic supply plus imports. These circumstances lead to higher price until the creation of a new equilibrium. Import restriction measures undertaken by Turkey will increase the price in the country at the same amount as tariff which will reduce import in that it will reduce demand for export from Indonesia.

Non-tariff barriers imposed on woven fabrics, stearic acid, and natural rubber is Quantitative Restrictions prohibitions, while palm oil are Sanitary and Phytosanitary, Quantitative Restrictions prohibitions, and Technical Barriers to Trade. Quantitative Restrictions made by Turkey in the form of a ban on importing products utilizing 
trademarks or ban illegal to import counterfeit labels and products for packaging as stated in WTO rule number G/MA/QR/N/TUR/1.

Factors Affecting Indonesian Import from Turkey
Factors affecting Indonesian export are determined by estimating regression towards each export commodity studied. The regression results are shown in Table 5.

Table 5. Regression Results of Indonesian Export Commodities

\begin{tabular}{lllll}
\hline \multicolumn{1}{c}{ Variable } & \multicolumn{1}{c}{ Carpets } & \multicolumn{1}{c}{ Borax } & \multicolumn{1}{c}{ Wheat Flour } & \multicolumn{1}{c}{ Tobacco } \\
\hline Ln_RGDPI & $4.04 \mathrm{E}-07^{* *}$ & $1.98 \mathrm{E}-06^{*}$ & $0.234477^{*}$ & $3.812236^{*}$ \\
Ln_Rexr & $-1.73 \mathrm{E}-07^{*}$ & $-3.55 \mathrm{E}-06^{*}$ & $-4.197100^{*}$ & $-3.195587^{*}$ \\
Ln_Imprice & $-2.38 \mathrm{E}-08^{*}$ & $-5.33 \mathrm{E}-06^{*}$ & $-2.872744^{*}$ & $-0.399475^{*}$ \\
TariffInd & $-1.000000^{*}$ & $-1.000000^{*}$ & $-0.019962^{*}$ & $-0.241070^{*}$ \\
DNTMIND & - & - & $-0.675789^{*}$ & - \\
C & $1.897119^{*}$ & $2.995764^{*}$ & $60.42377^{*}$ & $-25.07985^{*}$ \\
Rsquared & 0.927220 & 0.915200 & 0.890232 & 0.999317 \\
\hline
\end{tabular}

$\left({ }^{*}\right)$ significant at $5 \%$

$\left({ }^{* *}\right)$ significant at $10 \%$

\section{GDP per Capita}

GDP per capita of Indonesia provides positive and significant effect for Indonesia's commodities imported from Turkey. Results indicate conformity with the expected sign. GDP per capita will be positive effect because it shows the magnitude of the market. GDP per capita in this study indicate the level of welfare, the higher the level of prosperity, the higher the demand for import, which further increases the import value. The results are consistent with research conducted by Haider, et al. (2011) and Murad (2012) which showed positive correlation between the revenue/GDP with export and import. GDP will be positive influence on trade flows in terms of import because GDP measures the magnitude of the demand.
2. Real Exchange Rate

The real exchange rate (Ln_Rer) shows negative and significant relationship on imported commodities. The relationship indicated by the real exchange rate is consistent with the expected sign. Rising real exchange rate shows a depreciation of the rupiah so it will decrease import. This is according to the research conducted by Haider, et al. (2011) and Murad (2012) which also examined the effect of the currency on import. Currency depreciation can reduce import. Depreciation of the currency makes imported goods more expensive for domestic buyers, therefore, can reduce the demand for import.

3. Import price

Import price (Ln_imprice) gives negative and significant effect on the export of each commodity analyzed. Results are shown in accordance with the expected sign. 
This is in accordance with the law of supply and demand stating that the price increase will increase the offer which has lowered demand. This also applies to the export and import between countries. The high price of import results decline in import demand. Price elasticity ranged between $0.0000000238-2.872744$ with negative sign. This means an increase in price can reduce imports. Judging from the price elasticity, carpets, borax, and tobacco are inelastic commodities because the elasticities are less than one. While wheat flour is elastic commodity.

Results in price elasticity are in line with the research conducted by (Arora, 2015). Price elasticity on commodities studied shows that wheat flour is less price competitive when compared with other commodities, this is due to a change in price will lead to greater change in the value of import. Whereas in other commodities, change in the price causes smaller change in import value. Carpet has the smallest value of elasticity, therefore, carpet is the most competitive commodity among other commodities.

\section{Tariff Barriers}

Tariff (TariffInd) applied by Indonesia on products imported from Turkey gives negative and significant impact on each commodity studied. These results are consistent with the hypothesis of the study. Tariffs applied by a country making imported goods become more expensive and therefore reduce demand for import. Indonesia imposing tariffs on carpets of $40.0 \%$ in 1996-1997 then reduced in 1998 to $20.0 \%$ and in 2000-2014 became $15.0 \%$. Wheat flour was not subject to tariffs from the years 1996-2003 except 1998 the tariff was $5.0 \%$. Borax tariffs was $5.0 \%$ on the year from 1996 to 2014 except in 2008 and 2010 the rate charged at $2.5 \%$. Tobacco tariffs was $15.0 \%$ in 19961997 and was reduced to $5.0 \%$ after 1998.

5. Non-Tariff Barriers

Indonesia applies non-tariff barriers on wheat flour. The regression result indicates that nontariff barrier give significant and negative impact on wheat flour import. Non-tariff barrier imposed is in the form of anti-dumping.

The anti-dumping barrier has been established since 2014. This policy is applied based on the report of APTINDO (Indonesian Wheat Flour Producers Association) stated that there were anti-dumping allegations made by Turkey. APTINDO noted Turkey to cut prices by $2.8 \%$ in the first half of 2013 and increased to $35.3 \%$ in the second half of 2013 .

KADI (Indonesian AntiDumping Committee) reported that in the first half of 2013, Indonesia applied Temporary Duty Safety Measures (BMTPS) which causes a decrease in import volume of wheat flour in total. At the end of BMTPS period which was in the second half of 2013, there is an increase in the import volume of wheat flour by $51 \%$ compared to the first semester. Total import of wheat flour in Indonesia in 2013 is 205.448 tons. The import from countries that were accused of dumping was 176405 tons or $86 \%$ of total import. The 
share of import from each accused country accounting to $29 \%$ for India, $28 \%$ for Sri Lanka, and $29 \%$ for Turkey in the period of 2013.

\section{CONCLUSIONS}

1. $\mathrm{TCl}$ values in 2001-2018 ranged between 19-27. This low value of $\mathrm{TCl}$ indicates a low complementarity of Indonesia's export structure to import Turkey. Turkey is not Indonesia's main export destination. This also shows that Indonesia and Turkey are competitors.

2. Based on the commodity's share on each country's import as well as the combination of analysis of RCA and IIT, The top export commodities from Indonesia to Turkey are obtained, there are woven fabrics (HS 551611); stearic acid (HS 382311); palm oil (HS 151190); and natural rubber (HS 400122). While import commodities are based on the share in Indonesian import which are Carpets (HS 570242); Borax (HS 284019); Wheat flour (HS 110100); and tobacco (HS 240110)

3. GDP per capita gives positive and significant impact on export and import. The real exchange rate provides positive and significant impact on export, as well as significant and negative effect on import. Export price has significant and negative effect on export. Import price has significant and negative effect on import. Tariff barriers have significant and negative impact on export and import. Non-tariff barriers have significant and negative impact on export.

\section{IMPLICATION AND SUGGESTION}

Some suggestions for the government based on the results of this study are:

1. The Government should pursue a strategy in trade cooperation as efforts to reduce trade barriers such as tariffs and non-tariffs for some commodities that have competitiveness in the Turkish market. Reduction of tariffs especially for woven fabrics with $8 \%$ of tariff rate, stearic acid with $5.1 \%$, and palm oil with $24.9 \%$ of tariff rate which is increased from $8 \%$.

2. The government conducts a dissemination for the exporters on the standard to be met regarding to the Turkey's trade barriers, such as QR prohibitions, SPS, and TBT. So, the barriers will not affect Indonesia's export commodities.

3. Indonesia is one of main exporters of palm oil and natural rubber. There is a need for the development of products for the primary goods to continue increasing the competitiveness and produce derivative commodities. So hopefully, Indonesia is not only needed 
as a main source of material in the production process, but also develop into a supplier of processed commodities that will be much more profitable for Indonesia.

\section{REFERENCES}

Arora, T. (2015). FIW - Working Paper Export Competitiveness of Textile Commodities : A Panel Data Approach (No. 134).

Austria, M. S. (2004). The Pattern of Intra-ASEAN Trade in the Priority Goods Sectors Author : Retrieved from https: / / www.researchgate.net/ publication/265247076_The_Pat tern_of_IntraASEAN_Trade_in_the_Priority_G oods_Sectors?enrichld=rgreqc33eaa4d85e87bed658d59ee04d 61b82-

XXX\&enrichSource $=$ Y292ZXJQYW dIOzI2NTIONzA3NjtBUzozMTgXMj Q2NjUwNDkwODhAMTQ1Mjg1OD IzODk10Q\%3D\%3D\&el=1_x_2\&_e $\mathrm{sc}=$ publicationCoverPdf

Balassa, B. (1965). Trade Liberalisation and "Revealed" Comparative Advantage. The Manchester School, 33(2), 99123. https: / /doi.org/10.1111/j.1467 -9957.1965.tb00050.x

Haider, J., Afzal, M., \& Riaz, F. (2014). Estimation of import and export demand functions using bilateral trade data: The case of Pakistan. Business and Economic Horizons, 6, 40-53. https://doi.org/10.15208/beh.2 011.17

Krugman, P. R., \& Obsfeld, M. (2000). International Economics Theory and Policy.
Massachusetts, MA: An imprint of Addison Wesley Longman, Inc.

Murad, S. M. W. (2012). Bilateral Export and Import Demand Functions of Bangladesh: A Cointegration Approach. The Bangladesh Development Studies, XXXV(1), 43-60.

Oktaviani, R., Widyastutik, N., \& Novianti, T. (2017). Integrasi Perdagangan dan Dinamika Ekspor Indonesia ke Timur Tengah (Studi Kasus: Turki, Tunisia, dan Maroko). Jurnal Agro Ekonomi, 26(2), 167. https://doi.org/10.21082/jae.v 26n2.2008.167-189

Salvatore, D. (1997). International Economics. New Jersey, NJ: Prentice Hall-Gale.

United Nations Conference on Trade and Develpoment. (2012). Classification of Non-Tariff Measures. Retrieved from http://www.unctad.org

World Bank, International Trade Department. A Guide to Trade Data Analysis. Retrieved from http://www.siteresources.worl dbank.org

Yu, C. \& Qi, C. (2015). Research on the Complementarity and Comparative Advantages of Agricultural Product Trade between China and CEE Countries. Journal of Service Science and Management, 8(April), 201-208. 